\title{
Investigating Intraspecific Variation of Acidovorax avenae subsp. citrulli Using DNA Fingerprinting and Whole Cell Fatty Acid Analysis
}

\author{
R. R. Walcott, D. B. Langston, Jr., F. H. Sanders, Jr., and R. D. Gitaitis
}

University of Georgia, Coastal Plain Experiment Station, Tifton 31793.

Accepted for publication 3 November 1999.

\section{ABSTRACT}

Walcott, R. R., Langston, Jr., D. B., Sanders, Jr., F. H., and Gitaitis, R. D. 2000. Investigating intraspecific variation of Acidovorax avenae subsp. citrulli using DNA fingerprinting and whole cell fatty acid analysis. Phytopathology 90:191-196.

To assess the diversity of Acidovorax avenae subsp. citrulli, 121 strains from watermelon, cantaloupe, and pumpkin were compared using pulse field gel electrophoresis of SpeI-digested DNA and gas chromatographic analysis of fatty acid methyl esters. Twenty-nine unique DNA fragments resulted from DNA digestion, and 14 distinct haplotypes were observed. Based on cluster analysis, two subgroups, I and II, were recognized, which accounted for $84.8 \%$ (eight haplotypes) and $15.2 \%$ (six haplotypes) of the strains, respectively. Results of cellular fatty acid analysis varied quantitatively and qualitatively for the A. avenae subsp. citrulli strains and supported the existence of the two subgroups. Group I includes strains from cantaloupe and pumpkin as well as the ATCC type strain, which was first described in the United States in 1978, whereas group II represents the typical watermelon fruit blotch-causing strains that appeared in the mainland United States in 1989. Knowledge of the two A. avenae subsp. citrulli groups may be useful in screening for watermelon fruit blotch resistance.

Additional keywords: Citrullus lanatus.
Acidovorax avenae subsp. citrulli $(22,30)$ is the bacterial pathogen responsible for watermelon fruit blotch disease (WFB). Since the first natural outbreaks in the Mariana Islands and mainland United States in 1987 and 1989 (25,29), respectively, the disease has been reported in many of the watermelon (Citrullus lanatus (Thunb.) Matsum. \& Nakai)-producing states (9) and, more recently, it has been observed to cause disease on other cucurbit hosts including cantaloupe (Cucumis melo L. var. cantalupensis Naudin), honeydew (Cucumis melo L.), citron (Citrullus lanatus (Thunb.) Matsum. \& Nakai var. citroides (Bailey)), and pumpkin (Cucurbita pepo L.) $(12,13,16)$. Like many bacterial diseases, chemical control of WFB has been difficult to achieve (10), and disease management through the development of resistant cultivars remains an important control strategy. However, attempts to screen watermelon cultivars for resistance to A. avenae subsp. citrulli have yielded inconsistent results. While Sowell et al. (26) and Goth et al. (7) reported that certain watermelon cultivars (Wilhite Wonder, Mountain Hoosier, Garrisonian, and Congo) showed significant resistance to A. avenae subsp. citrulli, Hopkins et al. (11) could not reproduce their findings. One explanation for this discrepancy could be genetic variations in the A. avenae subsp. citrulli strains that were used (11). This strain diversity has not been demonstrated, but it is implied by the fact that the American Type Culture Collection (ATCC) A. avenae subsp. citrulli type strain did not cause a hypersensitive response (HR) on tobacco (22), while later strains of the WFB organism did (25). In addition, the type strain was reported to be mildly virulent on watermelon fruit (26), whereas strains identified since then were highly virulent (25). Differences between the type strain and the WFB-causing strain could not be determined by standard morphological, physiological, or biochemical tests (25).

Many techniques exist for studying the diversity of phytopathogenic organisms at the subspecific level. Among them, DNA finger-

Corresponding author: R. R. Walcott; E-mail address: rwalcott@arches.uga.edu

Publication no. P-1999-1220-01R

(c) 2000 The American Phytopathological Society printing by restriction endonuclease digestion and pulse field gel electrophoresis (PFGE) $(19,23)$ and fatty acid methyl ester (FAME) analysis $(17,20,21)$ have proven to be powerful discriminatory tools. DNA fingerprinting relies on the specific recognition and cleaving activity of restriction endonucleases to digest DNA molecules into fragments, followed by size fractionation by gel electrophoresis. The result is the generation of characteristic DNA fragment banding patterns. PFGE has been successfully employed to describe the genetic diversity of several bacterial species including Xanthomonas albilineans (2), X. campestris (4), and Ralstonia solanacearum (24).

FAME analysis has been used to characterize certain bacterial species including Erwinia chrysanthemi (1), Pseudomonas sp. (14), and $X$. campestris (27). This is possible because certain bacteria possess a range of fatty acid molecules in their cell walls, the composition and relative proportions of which are conserved when cells are grown under similar conditions. The objective of this study was to investigate the diversity of $A$. avenae subsp. citrulli with respect to PFGE DNA fingerprinting and fatty acid analysis.

\section{MATERIALS AND METHODS}

Bacterial strains. Between 1992 and 1999, 121 A. avenae subsp. citrulli strains were acquired for use in this study (Table 1). Strains were collected from fruit, seeds, and seedlings of watermelon, cantaloupe, and pumpkin from Georgia, Florida, California, and Indiana in the United States, and from Australia. Strains from Florida (AAC 96-1 to AAC 96-8) were provided by J. Jones and strain AAC 92-17 was donated by R. Latin. All other strains were collected by the authors and, in some cases, multiple strains were recovered from the same source.

To confirm pathogenicity, each $A$. avenae subsp. citrulli strain was inoculated onto a 2-week-old watermelon seedling cv. Starbrite under greenhouse conditions. Bacterial strains were grown on King's medium B (KMB) (15) at $28^{\circ} \mathrm{C}$ for $48 \mathrm{~h}$, and cells from an individual colony were used to seed $5 \mathrm{ml}$ of nutrient broth (NB) (Difco Laboratories, Detroit). After agitation at $28^{\circ} \mathrm{C}$ for $2 \mathrm{~h}$, cells were pelleted by centrifugation $(12,800 \times g)$ and resuspended in $5 \mathrm{ml}$ of $0.01 \mathrm{M}$ phosphate-buffered saline. Cell suspensions were ad- 
justed to approximately $10^{8} \mathrm{CFU} / \mathrm{ml}$ using a colorimeter (Spectronic 20; Bausch and Lomb Optical Co., Rochester, NY), and plants were inoculated by dipping a sterile needle into the suspension and pricking the seedlings along the hypocotyl. Seedlings were incubated on greenhouse benches for 7 days and observed for the development of typical WFB symptoms that included water-soaking and reddish-brown lesions along cotyledon midveins. Further strain verification was obtained by (i) indirect enzyme-linked immunosorbent assay (ELISA) using polyclonal antisera produced in-house against $A$. avenae subsp. citrulli (28); (ii) growth on semiselective media WFB $44\left(5 \mathrm{~g}\right.$ of NaCl, $1 \mathrm{~g}$ of $\mathrm{NH}_{4} \mathrm{PO}_{4}, 1 \mathrm{~g}$ of $\mathrm{KH}_{2} \mathrm{PO}_{4}, 0.2 \mathrm{~g}$ of $\mathrm{MgSO}_{4} \cdot 7 \mathrm{H}_{2} \mathrm{O}, 0.01 \mathrm{~g}$ of phenol red, $0.02 \mathrm{ml}$ of pourite, $0.2 \mathrm{~g}$ of berberine, $0.01 \mathrm{~g}$ of methyl violet $\mathrm{B}, 25 \mathrm{~g}$ of carboxymethyl cellulose, $5 \mathrm{~g}$ of Bacto-agar [Difco Laboratories], $0.03 \mathrm{~g}$ of ceflaclor, and 1 liter of distilled water) and WFB 68 (5 g of Bacto-peptone [Difco Laboratories], $0.25 \mathrm{~g}$ of $\mathrm{CaCl}_{2} .2 \mathrm{H}_{2} \mathrm{O}, 10 \mathrm{ml}$ of Tween 80 , $0.2 \mathrm{~g}$ of berberine, $0.01 \mathrm{~g}$ of methyl violet $\mathrm{B}, 15 \mathrm{~g}$ of Bacto-agar [Difco Laboratories], $0.05 \mathrm{~g}$ of carbenicillin, and 1 liter of deionized water); (iii) the inability to utilize malonate (8); (iv) and a polymerase chain reaction (PCR) assay using primers RST 49/51 (18).

DNA fingerprinting. Bacterial strains were grown on $\mathrm{KMB}$ at $28^{\circ} \mathrm{C}$ for $48 \mathrm{~h}$, and $4 \mathrm{ml}$ of NB were seeded with cells from a single colony of each culture. After incubation at $28^{\circ} \mathrm{C}$ for $12 \mathrm{~h}$, cell suspensions were adjusted to an optical density of 0.3 (approximately $5 \times 10^{8} \mathrm{CFU} / \mathrm{ml}$ ) at $600 \mathrm{~nm}$ using a colorimeter. Aliquots of $1.5 \mathrm{ml}$ of each cell suspension were pelleted by centrifugation at $12,800 \times g$ for $2 \mathrm{~min}$, resuspended in $1 \mathrm{ml}$ of sterile distilled water, pelleted again, and resuspended in $500 \mu \mathrm{l}$ of $1 \times$ Tris-acetate-EDTA (TAE) buffer (40 mM Tris, $40 \mathrm{mM}$ acetic acid, and $1 \mathrm{mM}$ EDTA). Five hundred microliters of molten low-melting-point agarose $(10 \mathrm{mM}$ Tris, $\mathrm{pH} 8.0 ; 10 \mathrm{mM} \mathrm{MgCl} 2 ; 10 \mathrm{mM}$ EDTA, $\mathrm{pH} \mathrm{8.0;} \mathrm{and} 2 \%$ [wt/vol] SeaPlaque GTG agarose [FMC BioProducts, Rockland, $\mathrm{ME}]$ ) was mixed with the cell suspensions and pipetted into dis- posable plastic plug-molds (Bio-Rad Laboratories, Fullerton, CA). Agarose plugs were solidified at $4{ }^{\circ} \mathrm{C}$ for $20 \mathrm{~min}$ and transferred to polypropylene tubes containing $2 \mathrm{ml}$ of lysing solution $(0.6 \mathrm{mg}$ of proteinase $\mathrm{K}$ per $\mathrm{ml}$; $1 \% \mathrm{~N}$-lauryl sarkosyl; $25 \%$ sodium dodecyl sulfate; and $250 \mathrm{mM}$ EDTA, pH 9.5). The embedded cells were lysed by incubation at $55^{\circ} \mathrm{C}$ for $12 \mathrm{~h}$, followed by six rinses with sterile $1 \times$ TAE over 6 to $8 \mathrm{~h}$. The plugs were then transferred to new polypropylene tubes containing $5 \mathrm{ml}$ of sterile $250 \mathrm{mM}$ EDTA (pH 8.0) and stored at $4^{\circ} \mathrm{C}$.

For DNA digestion, agarose plugs were cut into $5 \times 5 \times 1-\mathrm{mm}$ pieces and rinsed four times with $1 \mathrm{ml}$ of sterile $1 \times$ TAE $(30-\mathrm{min}$ rinses). The $1 \times$ TAE was replaced with $200 \mu \mathrm{l}$ of $1 \times$ restriction enzyme buffer B (Promega Corp., Madison, WI), and the plugs were incubated at $25^{\circ} \mathrm{C}$ for $15 \mathrm{~min}$. The restriction buffer was replaced with $200 \mu \mathrm{l}$ of fresh restriction buffer containing $1 \mu \mathrm{l}$ of SpeI (Promega Corp.), and the agarose plugs were incubated at $37^{\circ} \mathrm{C}$ overnight. The restriction buffer was then replaced with $500 \mu \mathrm{l}$ of lysing solution without proteinase $\mathrm{K}$, and the plugs were incubated at $55^{\circ} \mathrm{C}$ for $2 \mathrm{~h}$. The lysing solution was replaced with fresh lysing solution without proteinase $\mathrm{K}$, and the agarose plugs were incubated at $25^{\circ} \mathrm{C}$ for an additional $2 \mathrm{~h}$. The agarose plugs were then loaded into wells of a $1 \%$ (wt/vol) pulse field certified agarose (Bio-Rad Laboratories) gel and sealed with molten lowmelting-point agarose. Saccharomyces cerevisiae chromosomal DNA (Bio-Rad Laboratories) was used as a molecular weight marker. The loaded gel was incubated in $0.5 \times$ Tris-borate-EDTA (TBE) buffer (45 mM Tris; $45 \mathrm{mM}$ boric acid; and $1 \mathrm{mM}$ EDTA, $\mathrm{pH}$ 8.0) for $30 \mathrm{~min}$ prior to electrophoresis. Electrophoresis was conducted on a contour-clamped homogenous electric field gel electrophoresis unit (CHEF-DR III; Bio-Rad Laboratories) for $22 \mathrm{~h}$ at $6 \mathrm{~V} / \mathrm{cm}$ in $0.5 \times \mathrm{TBE}$ buffer, with initial and final switch times of 5 and $45 \mathrm{~s}$, respectively. After electrophoresis, gels were stained with a solution of $0.5 \mu \mathrm{g}$ of ethidium bromide per $\mathrm{ml}$ for $30 \mathrm{~min}$,

TABLE 1. Designation, geographical origin, source, and other relevant characteristics of Acidovorax avenae subsp. citrulli strains

\begin{tabular}{|c|c|c|c|c|c|}
\hline Strain & Geographical origin & Source & Date acquired & Host & Haplotype \\
\hline AAC 00-1, 92-307 & Unknown & Gitaitis & 1992 & Citron & A \\
\hline AAC 92-1 & Lee Co. GA & Gitaitis & 1992 & Watermelon & A \\
\hline AAC 92-2, 3, 4, 5, 6 & Appling Co. GA & Gitaitis & 1992 & Watermelon & A \\
\hline AAC 92-7 & Cook Co. GA & Gitaitis & 1992 & Watermelon & A \\
\hline AAC 92-10 & Colquit Co. GA & Gitaitis & 1992 & Watermelon & A \\
\hline AAC 92-11, 12 & Unknown & Gitaitis & 1992 & Watermelon & A \\
\hline AAC 92-17 & Indiana & Latin & 1992 & Watermelon & $\mathrm{D}$ \\
\hline ATCC 29625 & Georgia & $\mathrm{ATCC}^{\mathrm{a}}$ & 1992 & Watermelon & $\mathrm{K}$ \\
\hline AAC 92-301 & Unknown & Gitaitis & 1992 & Watermelon & $\mathrm{F}$ \\
\hline AAC 92-302 & Unknown & Gitaitis & 1992 & Watermelon & $\mathrm{H}$ \\
\hline AAC 92-303, 304 & Unknown & Gitaitis & 1992 & Watermelon & $\mathrm{B}$ \\
\hline AAC 92-305 & Unknown & Gitaitis & 1992 & Watermelon & $\mathrm{I}$ \\
\hline AAC 92-308 & Georgia & Gitaitis & 1992 & Watermelon & A \\
\hline AAC 93-300 & California & Gitaitis & 1993 & Watermelon & $\mathrm{E}$ \\
\hline AAC 94-11, 12 & Unknown & Gitaitis & 1994 & Watermelon & $\mathrm{H}$ \\
\hline AAC $94-16,17,18,20,21,22,26,31,32$ & Unknown & Gitaitis & 1994 & Watermelon & $\mathrm{C}$ \\
\hline AAC 94-23 & Georgia & Gitaitis & 1994 & Citron & A \\
\hline AAC 94-24, 27, 28, 29 & Unknown & Gitaitis & 1994 & Watermelon & $\mathrm{G}$ \\
\hline AAC $94-25,33,34,35,37$ & Unknown & Gitaitis & 1994 & Watermelon & $\mathrm{E}$ \\
\hline AAC $94-30,36$ & Unknown & Gitaitis & 1994 & Watermelon & $\mathrm{B}$ \\
\hline AAC $94-38,39,40,41,42$ & Wilcox Co. GA & Gitaitis & 1994 & Watermelon & $\mathrm{J}$ \\
\hline AAC $94-43,44,45,46,47,48,52,55$ & Wilcox Co. GA & Gitaitis & 1994 & Watermelon & $\mathrm{E}$ \\
\hline AAC 94-56 & Wilcox Co. GA & Gitaitis & 1994 & Watermelon & $\mathrm{B}$ \\
\hline АAC 94-58, 59, 60, 61, 62, 63, 64, 65, 67, 68, 69 & Tift Co. GA & Gitaitis & 1994 & Citron & $\mathrm{C}$ \\
\hline \multicolumn{6}{|l|}{ AAC $94-70,71,72,73,74,75,76,77,78,79,80$, } \\
\hline $81,82,83,84,85,86,87,88,89$ & Unknown & Gitaitis & 1994 & Watermelon & G \\
\hline AAC $95-1,2,3$ & Unknown & Gitaitis & 1995 & Watermelon & $\mathrm{C}$ \\
\hline AAC $52-6$ & Crisp Co. GA & Walcott & 1996 & Watermelon & $\mathrm{C}$ \\
\hline AAC $96-1,2,3,4,5,6,7,8$ & Florida & Jones & 1996 & Watermelon & G \\
\hline AAC 97-1 & Worth Co. GA & Walcott & 1997 & Watermelon & $\mathrm{C}$ \\
\hline AAC 98-3 & Australia & Gitaitis & 1998 & Cantaloupe & $\mathrm{B}$ \\
\hline AAC $98-4,5,6$ & Australia & Gitaitis & 1998 & Cantaloupe & $\mathrm{L}$ \\
\hline AAC $98-7,8,9,10,11,12,13,14,15$ & Australia & Gitaitis & 1998 & Cantaloupe & M \\
\hline AAC $98-16,17$ & Terrell Co. GA & Langston & 1998 & Pumpkin & $\mathrm{N}$ \\
\hline AAC 99-1, 2, 3 & Australia & Gitaitis & 1998 & Cantaloupe & $\mathrm{M}$ \\
\hline
\end{tabular}

a ATCC $=$ American Type Culture Collection. 
and digital images were captured under ultraviolet transillumination using a Kodak DC-40 digital camera (Eastman Kodak Co., New Haven, CT).

FAME analysis. A. avenae subsp. citrulli strains were grown on tryptic soy broth agar (Difco Laboratories) at $28^{\circ} \mathrm{C}$ for $24 \mathrm{~h}$. Extraction and analysis of FAMEs were conducted on each strain according to previously described methods (6).

Data analysis. A. avenae subsp. citrulli strains were assigned to haplotypes based on visual assessment of their DNA banding patterns, and individual strains representing each haplotype were compared on the same gel. For cluster analysis of the haplotypes, DNA fragment migration distances were measured using Kodak 1D Digital Sciences gel imaging software (Eastman Kodak Co.), and fragments separated by greater than 10 pixels (smallest unit of resolution on a digitized image) were considered different. DNA migration patterns were used to generate binary data based on the presence or absence of DNA fragments of unique size. Pairwise similarity between haplotypes was determined using Dice's coefficient (3), in which $\mathrm{S}_{x y}$ is the pairwise similarity index (SI); $n_{x y}$ is the number of bands common to each haplotype; and $n_{x}$ and $n_{y}$ are the total number of bands in each haplotype. Dissimilarity or distance indices were calculated from the SIs $\left(D_{x y}=\right.$ $1-\mathrm{S}_{x y}$ ) and the distance matrix data were used for cluster analysis by the unweighted pair group method with arithmetic means (UPGMA) algorithm using the NEIGHBOR program of the PHYLIP phylogenetic software package (version $3.5 \mathrm{c}$; J.

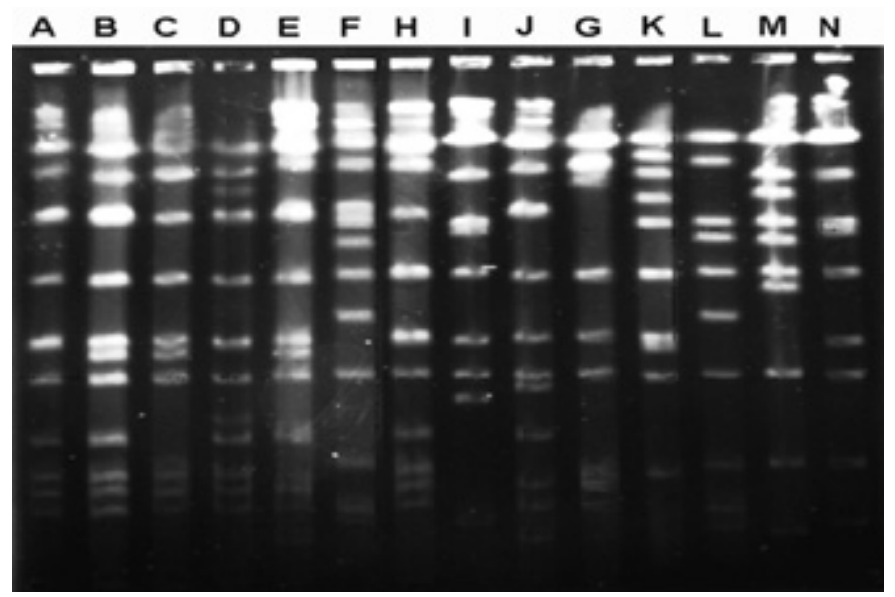

Fig. 1. Pulse field gel electrophoresis DNA fingerprints of Acidovorax avenae subsp. citrulli strains representing different haplotypes. DNA fingerprints were generated by digestion with SpeI. Lanes A to N contain strains AAC 00-1 (haplotype A), AAC 94-30 (haplotype B), AAC 94-20 (haplotype C), AAC 92-17 (haplotype D), AAC 94-25 (haplotype E), AAC 92-305 (haplotype F), AAC 94-11 (haplotype H), AAC 92-301 (haplotype I), AAC 94-40 (haplotype J), AAC 94-70 (haplotype G), ATCC 29625 (haplotype K), AAC 98-4 (haplotype L), AAC 98-9 (haplotype M), and AAC 98-17 (haplotype N).
Felsenstein, University of Washington, Seattle). The robustness of the groups established by cluster analysis were assessed by bootstrap analysis using the Winboot computer program (International Rice Research Institute, Manila, Philippines). Trees were reconstructed 2,000 times by repeated pseudosampling with replacement, and the frequency at which a particular grouping occurred indicated its robustness.

Based on FAME composition, the relationships among 68 strains representing all $A$. avenae subsp. citrulli haplotypes were determined by cluster and principle component analysis using the Microbial Identification System software version 3.6 (Microbial ID, Inc., Newark, DE).

\section{RESULTS}

None of the A. avenae subsp. citrulli strains utilized malonate as a carbon source, and all tested positive with ELISA, PCR, and growth on semiselective media. In addition, all strains except ATCC 29625 caused typical WFB symptoms on 2-week-old watermelon seedlings.

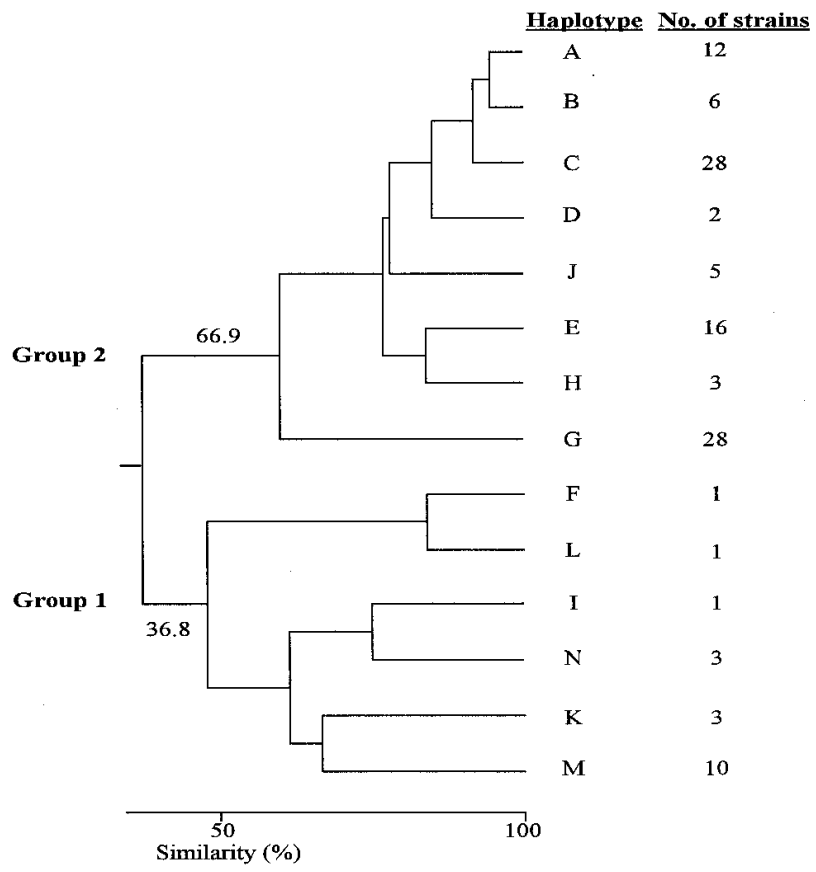

Fig. 2. Dendrogram showing the relationships among Acidovorax avenae subsp. citrulli pulse field gel electrophoresis haplotypes. The tree was derived from cluster analysis of distances between haplotypes using the unweighted pair group method with arithmetic means. Numbers on branches are bootstrap values indicating the robustness of clusters to the right.

TABLE 2. Similarity values generated by Dice's coincidence index for SpeI-digested DNA profiles for an Acidovorax avenae subsp. citrulli strain representing each haplotype

\begin{tabular}{|c|c|c|c|c|c|c|c|c|c|c|c|c|c|c|}
\hline Haplotype & A & B & C & D & E & F & G & $\mathrm{H}$ & I & $\mathrm{J}$ & $\mathrm{K}$ & $\mathrm{L}$ & M & $\mathrm{N}$ \\
\hline A & 1.00 & & & & & & & & & & & & & \\
\hline B & 0.95 & 1.00 & & & & & & & & & & & & \\
\hline $\mathrm{C}$ & 0.90 & 0.95 & 1.00 & & & & & & & & & & & \\
\hline E & 0.76 & 0.82 & 0.76 & 0.70 & 1.00 & & & & & & & & & \\
\hline $\mathrm{F}$ & 0.48 & 0.45 & 0.48 & 0.43 & 0.55 & 1.00 & & & & & & & & \\
\hline G & 0.63 & 0.60 & 0.63 & 0.57 & 0.70 & 0.50 & 1.00 & & & & & & & \\
\hline $\mathrm{H}$ & 0.90 & 0.86 & 0.80 & 0.82 & 0.86 & 0.57 & 0.74 & 1.00 & & & & & & \\
\hline K & 0.50 & 0.48 & 0.50 & 0.45 & 0.38 & 0.38 & 0.53 & 0.40 & 0.63 & 0.48 & 1.00 & & & \\
\hline $\mathrm{L}$ & 0.40 & 0.38 & 0.40 & 0.36 & 0.48 & 0.86 & 0.63 & 0.50 & 0.53 & 0.38 & 0.50 & 1.00 & & \\
\hline M & 0.40 & 0.38 & 0.40 & 0.36 & 0.29 & 0.57 & 0.42 & 0.30 & 0.63 & 0.38 & 0.70 & 0.70 & 1.00 & \\
\hline $\mathrm{N}$ & 0.42 & 0.50 & 0.53 & 0.38 & 0.40 & 0.50 & 0.44 & 0.32 & 0.78 & 0.40 & 0.63 & 0.63 & 0.74 & 1.00 \\
\hline
\end{tabular}


TABLE 3. Cellular fatty acid composition of Acidovorax avenae subsp. citrulli strains representing the different haplotype groups and the similarity of their fatty acid profiles to ATCC 29625 (type strain)

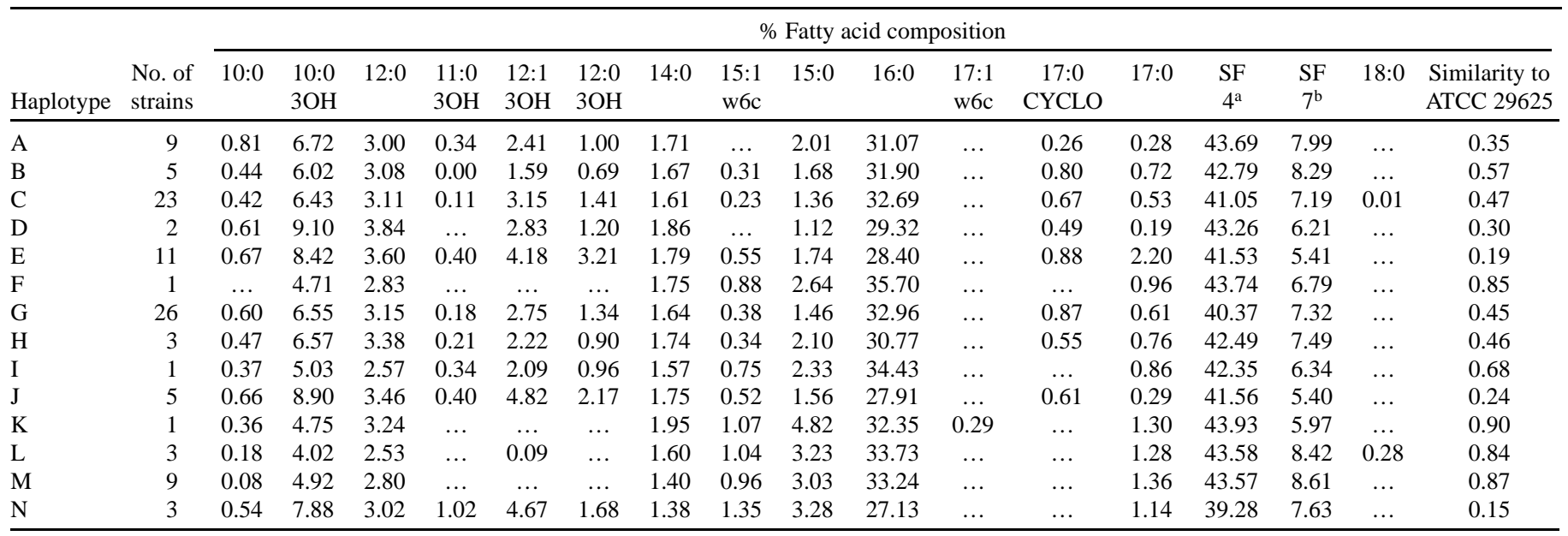

${ }^{\text {a }}$ Summed feature 4 represents a combination of $16: 1 \mathrm{w} 7 \mathrm{c}$ and 15 iso $2 \mathrm{OH}$ fatty acids.

${ }^{\mathrm{b}}$ Summed feature 7 represents the combination of $18: 1 \mathrm{w} 7 \mathrm{c} / \mathrm{w} 9 \mathrm{t} / \mathrm{w} 12 \mathrm{t}$ and $18: 1 \mathrm{w} 9 \mathrm{c} / \mathrm{w} 12 \mathrm{t} / \mathrm{w} 7 \mathrm{c}$ fatty acids.

\section{Euclidian Distance}

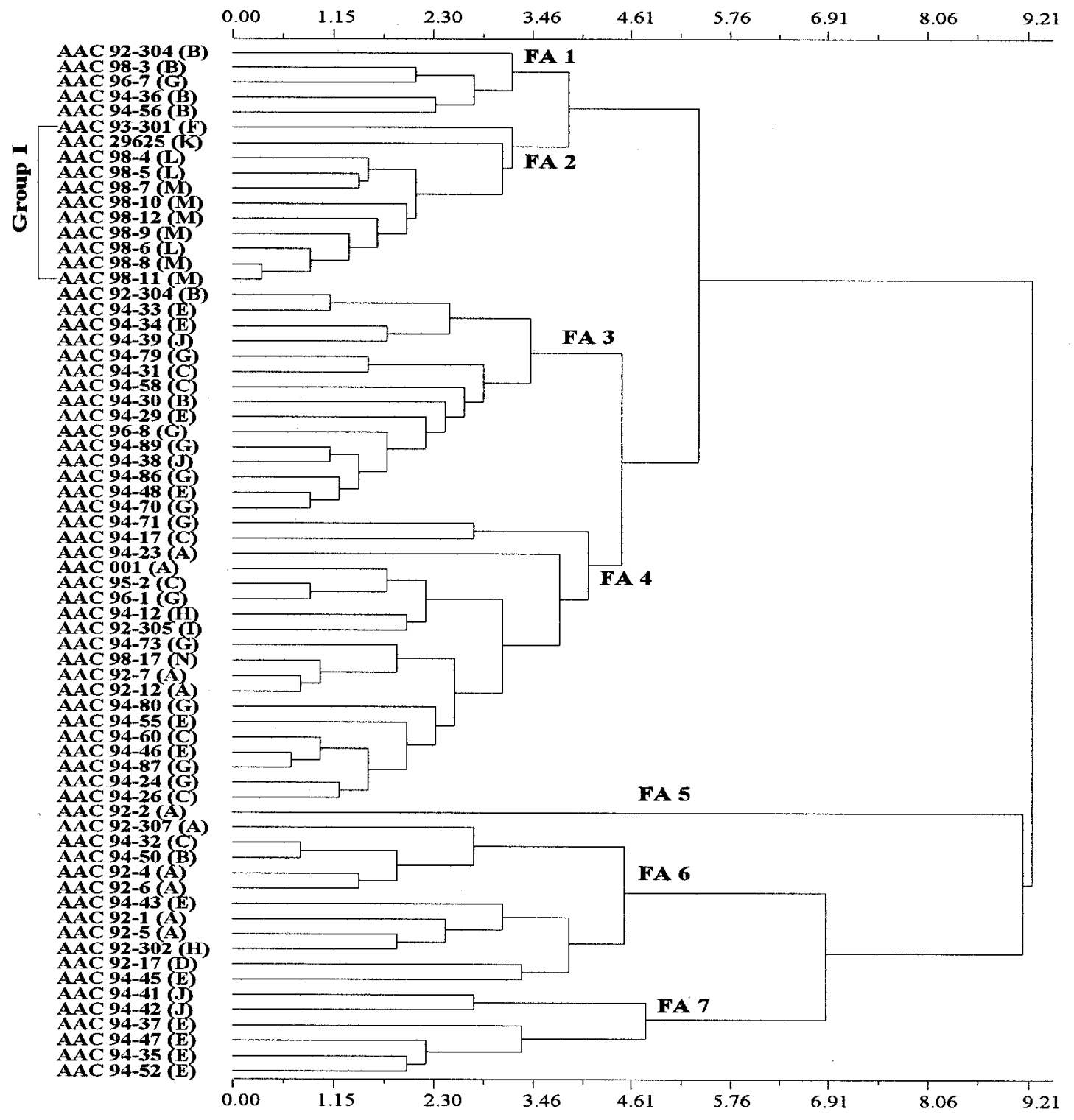

Fig. 3. Dendrogram generated by cluster analysis of 68 Acidovorax avenae subsp. citrulli strains based on fatty acid composition, using the Microbial Identification System software package (Microbial ID, Inc., Newark, DE). Letters in parentheses represent the haplotype to which the strain belongs. FA= fatty acid group. 
SpeI digested DNA from all A. avenae subsp. citrulli strains and yielded 9 to 12 fragments per strain. Twenty-nine different DNA fragments were scored, and 14 banding patterns (haplotypes) were identified (Fig. 1). Haplotypes were designated A to N, with the majority of strains occurring in haplotypes $\mathrm{G}$ and $\mathrm{C}(47.05 \%)$. On the other hand, haplotypes $\mathrm{F}, \mathrm{I}$, and $\mathrm{K}$ consisted of single strains (AAC 92-301, AAC 92-305, and ATCC 29625, respectively). Similarity coefficients of $A$. avenae subsp. citrulli haplotypes ranged from 0.29 (haplotypes $\mathrm{E}$ and $\mathrm{M}$ ) to 0.95 (haplotypes $\mathrm{A}$ and $\mathrm{B}$ ), and the ATCC type strain (haplotype K) had an average similarity coefficient of 0.47 when compared with other haplotypes (Table 2). Using UPGMA cluster analysis, two distinct groups were identified (Fig. 2). Group I consisted of haplotypes F, I, $\mathrm{K}, \mathrm{L}, \mathrm{M}$, and $\mathrm{N}$ (15.2\% of strains), and group II consisted of haplotypes A, B, C, D, E, G, H, and J (84.8\% of strains). Bootstrap values for the clusters were low (36.8 and $66.9 \%$ for groups I and II, respectively), indicating that they were not robust (Fig. 2).

Fatty acid composition varied for all A. avenae subsp. citrulli strains, and 18 different fatty acids were detected (Table 3). All strains contained high proportions of 16:0 (37.47\%), 16:1 w7c, and 15 iso $2 \mathrm{OH}(42.37 \%)$ fatty acids. Only the ATCC type strain (haplotype K) contained 17:1 w6c. The 11:0 3OH, 12:1 3OH, 12:0 3OH, and 17:0 cyclopropane fatty acids were absent or present in low proportions in many of the strains that composed subgroup I (F, K, L, and M). These included the ATCC type strain, AAC 92-305, and strains from watermelon and cantaloupe, except AAC AU-1. Unexpectedly, these particular fatty acids were present in haplotypes I and N, even though these strains were included in subgroup I by DNA fingerprinting (Fig. 2).

Grouping of $A$. avenae subsp. citrulli strains by fatty acid composition suggested the existence of seven groups (Fig. 3); however, many of the group I strains (haplotypes K, L, M, and F) still composed a single group (fatty acid group 2). Exceptions to this were haplotypes I and N, which were placed in fatty acid group 4. Similar results were obtained when principle component analysis was conducted on the fatty acid composition data for A. avenae subsp. citrulli strains (Fig. 4). A plot of the first three principle components revealed a discrete cluster that contained the group I strains, except haplotypes I and N. In addition, the average SI values generated by comparing fatty acid profiles of A. avenae subsp. citrulli strains with the ATCC type strain were greater for group I (0.715) than for group II (0.39) (Table 3). Despite the relatively high range of SI values for group I (0.68 to 0.90$)$, haplotype $\mathrm{N}$ strains had a low mean SI value (0.15), suggesting that they were outliers.

\section{DISCUSSION}

While the A. avenae subsp. citrulli strains used in this study could not be distinguished based on PCR, growth on semiselective media, or ELISA with polyclonal antibodies, fatty acid analysis and DNA fingerprinting provided evidence of intraspecific diversity. DNA fingerprinting revealed the existence of 14 haplotypes that clustered into two groups (I and II). Group II contained $84.8 \%$ of the A. avenae subsp. citrulli strains tested and consisted of strains from watermelon fruits, seeds, and seedlings from Indiana, California, Florida, and Georgia. The remaining strains composed group I and included the ATCC type strain and strains recovered from pumpkin from Georgia and cantaloupe from Australia. One unexpected result was the clustering of the Australian strain, AAC 98-3, with group II, even though other cantaloupe strains belonged to group I. This can be explained by the fact that AAC 98-3 was isolated from a watermelon and may have been introduced into Australia from a seedlot originating in the United States. This also accounts for its similarity to other WFB-causing (group II) strains. The ability to distinguish AAC 98-3 from the other Australian strains demonstrates the discriminative power of PFGE DNA fingerprinting.
Despite low bootstrap values for the haplotype clusters, FAME analysis provided evidence to support the existence of the two $A$. avenae subsp. citrulli groups. Fatty acid group 2 included the ATCC A. avenae subsp. citrulli type strain, AAC 92-301, and the Australian cantaloupe strains, but excluded the pumpkin strains and AAC 92305 (haplotypes I and N, respectively). Similar conclusions could be drawn from principle component analysis and observation of the SI values comparing the A. avenae subsp. citrulli strains with the ATCC type strain. Despite similarities within the group I strains, the ATCC type strain still differed from the others by its inabilities to produce a HR on tobacco and to infect watermelon seedlings in this study. It is possible that the type strain's lack of pathogenicity was due to mutations arising during long-term storage or continued growth on culture media. However, its inability to elicit a HR suggests that there are other physiological differences between the type strain and the other WFB-causing strains.

Although AAC 98-17 and AAC 98-16 (haplotype N) were excluded from group I based on FAME analysis, they failed to infect watermelon fruits during a natural outbreak in a mixed planting of pumpkins and watermelons (16). This reduced virulence on watermelon fruits supports the placement of haplotype $\mathrm{N}$ in group $\mathrm{I}$. However, another explanation could be that the inoculum originated on the pumpkin plants and arrived on the watermelons after they were physiologically resistant to natural infection (5).

From this study, it is clear that the ATCC A. avenae subsp. citrulli type strain culture used in this study was not typical of the WFB-causing strains from watermelon. It is likely that the inability of Hopkins et al. (9) to find susceptibility differences in cvs. Congo and Garrisonian seedling reactions to A. avenae subsp. citrulli (7, 26) was due to the use of a more virulent WFB-causing (group II) strain as opposed to the type strain (group I). However, it is also possible that different experimental conditions were used.

Despite its dissimilarity to the WFB-causing bacteria, the ATCC strain is still maintained as the representative A. avenae subsp. citrulli strain. It is suggested that researchers screening watermelon cultivars for resistance to WFB take into consideration the A. avenae subsp. citrulli population structure demonstrated in this study. The data presented provide the framework for further investigation of the evolutionary, ecological, and epidemiological significance of A. avenae subsp. citrulli.

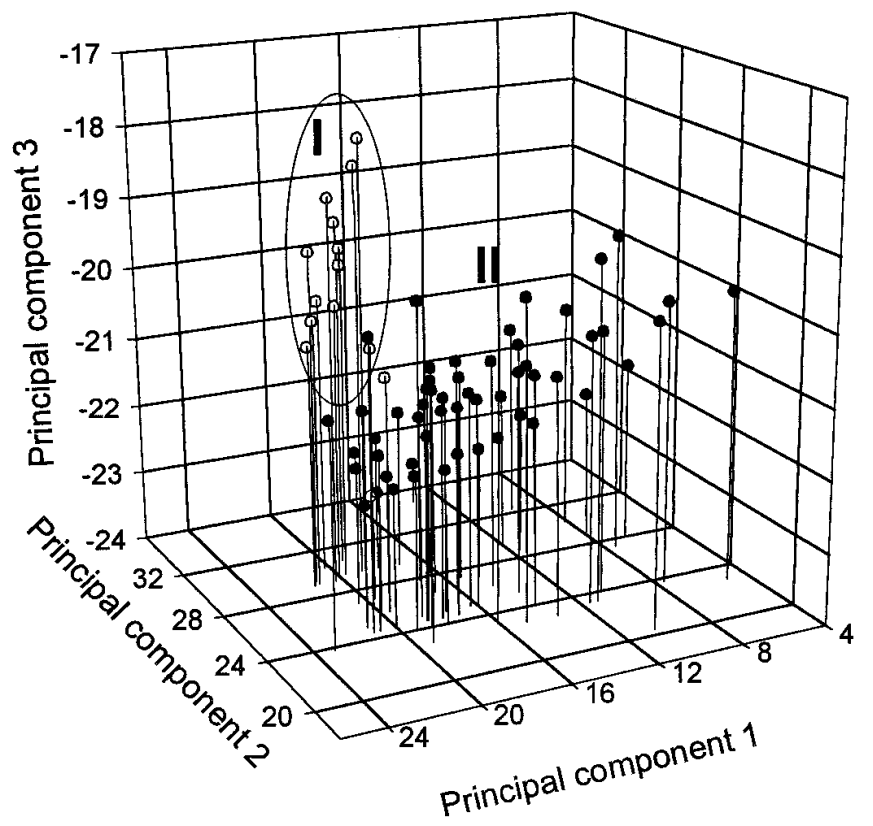

Fig. 4. Plot of the first three principle components derived from fatty acid methyl ester profiles of 68 Acidovorax avenae subsp. citrulli strains representing different haplotypes. White and black circles represent group I and II strains, respectively. 


\section{ACKNOWLEDGMENTS}

We thank B. Stall and J. Minsavage for their technical assistance. We also thank R. Latin and J. Jones for contributing strains of Acidovorax avenae subsp. citrulli.

\section{LITERATURE CITED}

1. Cother, E. J., Bradley, J. K., Gillings, M. R., and Fahy, P. C. 1992. Characterization of Erwinia chrysanthemi biovars in alpine water sources by biochemical properties, GLC fatty acid analysis and genomic DNA fingerprinting. J. Appl. Bacteriol. 73:99-107.

2. Davis, M. J., Rott, P., Warmuth, C. J., Chatenet, M., and Baudin, P. 1997. Intraspecific genomic variation within Xanthomonas albilineans, the sugarcane leaf scald pathogen. Phytopathology 87:316-324.

3. Dice, L. R. 1945. Measures of the amount of ecologic association between species. Ecology 26:297-302.

4. Egel, D. S., Graham, J. H., and Stall, R. E. 1991. Genomic relatedness of Xanthomonas campestris strains causing disease of citrus. Appl. Environ. Microbiol. 57:2724-2730.

5. Frankle, W. G., Hopkins, D. L., and Stall, R. E. 1993. Ingress of the watermelon fruit blotch bacterium into fruit. Plant Dis. 77:1090-1092.

6. Gitaitis, R. D., and Beaver, R. W. 1990. Characterization of fatty acid methyl ester content of Clavibacter michiganensis subsp. michiganensis. Phytopathology 80:318-321.

7. Goth, R. W., and Webb, R. E. 1981. Resistance of commercial watermelon (Citrullus lanatus) to Pseudomonas pseudoalcaligenes subsp. citrulli. Plant Dis. 65:671-672.

8. Hodge, N. C., Baird, S. M., Gitaitis, R. G., Hopkins, D. L., and Stall, R. E. 1995. A bacterium related to Acidovorax facilis occurs on watermelon seedlings. (Abstract) Phytopathology 85:1187.

9. Hopkins, D., Stall, B., Kucharek, T., Gay, D., Gitaitis, R., Cook, W., Kienath, A., and Latin, R. 1995. Bacterial fruit blotch of watermelon. University of Florida, Gainesville; University of Georgia, Athens; Clemson University, Clemson, SC; and Purdue University, West Lafayette, IN.

10. Hopkins, D. L. 1991. Control of bacterial fruit blotch of watermelon with cupric hydroxide. (Abstr.) Phytopathology 81:1228.

11. Hopkins, D. L., Thompson, C. M., and Elmstrom, G. W. 1993. Resistance of watermelon seedlings and fruit to the fruit blotch bacterium. Hortscience 28:122-123.

12. Isakeit, T., Black, M. C., Barnes, L. W., and Jones, J. B. 1997. First report of infection of honeydew with Acidovorax avenae subsp. citrulli. Plant Dis. 81:694.

13. Isakeit, T., Black, M. C., and Jones, J. B. 1998. Natural infection of citronmelon with Acidovorax avenae subsp. citrulli. Plant Dis. 82:351.

14. Janse, J. D., Derks, J. H. J., Spit, B. E., and Van Der Tuin, W. R. 1992. Classification of fluorescent soft rot Pseudomonas bacteria, including $P$. marginalis strains, using whole cell fatty acid analysis. Syst. Appl. Mi- crobiol. 15:538-553.

15. King, E. O., Ward, M. K., and Raney, D. E. 1956. Two simple media for the demonstration of pyocyanin and fluorescin. J. Lab. Clin. Med. 44: 301-307.

16. Langston, Jr., D. B., Walcott, R. R., Gitaitis, R. D., and Sanders, Jr., F. H. 1999. First report of a fruit rot of pumpkin caused by Acidovorax avenae subsp. citrulli in Georgia. Plant Dis. 83:199.

17. Miller, L., and Berger, T. 1985. Bacteria identification by gas chromatography of whole cell fatty acids. Hewlett-Packard Gas Chromatography Application Note 228-238. Hewlett-Packard Co., Palo Alto, CA.

18. Minsavage, G. V., Hoover, R. J., Kucharek, T. A., and Stall, R. E. 1995. Detection of the watermelon fruit blotch pathogen on seeds with the polymerase chain reaction. (Abstr.) Phytopathology 85:1162.

19. Salama, S. M., Tabor, H., Richter, M., and Taylor, D. E. 1992. Pulse-field gel electrophoresis for epidemiologic studies of Campylobacter hyointestinalis isolates. J. Clin. Microbiol. 30:1982-1984.

20. Sasser, M. J. 1990. Identification of bacteria through fatty acid analysis. Pages 199-204 in: Methods in Phytobacteriology. Z. Klement, K. Rudolph, and D. Sands, eds. Akademiai Kiado, Budapest.

21. Sasser, M. J., Fieldhouse, D. J., and Carter, C. N. 1984. Computer assisted identification of bacteria based on fatty acid analysis. (Abstr.) Phytopathology 74:882.

22. Schaad, N. W., Sowell, G., Goth, R. W., Colwell, R. R., and Webb, R. E. 1978. Pseudomonas pseudoalcaligenes subsp. citrulli subsp. nov. Int. J. Syst. Bacteriol. 28:117-125.

23. Schwartz, D., and Cantor, C. 1984. Separation of yeast chromosomesized DNAs by pulse field electrophoresis. Cell 37:67-75.

24. Smith, J. J., Olford, L. C., Holderness, M., and Saddler, G. S. 1995. Pulse field gel electrophoresis analysis of Pseudomonas solanacearum. OEP/EPPO Bull. 25:163-167.

25. Somodi, G. C., Jones, J. B., Hopkins, D. L., Stall, R. E., Kucharek, T. A., Hodge, N. C., and Watterson, J. C. 1991. Occurrence of bacterial watermelon fruit blotch in Florida. Plant Dis. 75:1053-1056.

26. Sowell, Jr., G., and Schaad, N. W. 1979. Pseudomonas pseudoalcaligenes subsp. citrulli on watermelon: Seed transmission and resistance of plant introductions. Plant Dis. Rep. 63:437-441.

27. Stead, D. E. 1989. Grouping of Xanthomonas campestris pathovars of cereals and grasses by fatty acid profiling. EPPO Bull. 19:57-68.

28. Walcott, R. R. 1999. Genetic diversity of A. avenae subsp. citrulli ((Schaad et al.) Willems et al.) and the rapid detection of the pathogen in watermelon seeds. Ph.D. dissertation. The University of Georgia, Athens.

29. Wall, G. C., and Santos, V. M. 1988. A new bacterial disease on watermelon in the Mariana Islands. (Abstr.) Phytopathology 78:1605.

30. Willems, A., Goor, M., Thielemans, S., Gilis, M., Kersters, K., and De Ley, J. 1992. Transfer of several phytopathogenic Pseudomonas species to Acidovorax as Acidovorax avenae subsp. avenae subsp. nov., comb. nov., Acidovorax avenae subsp. citrulli, Acidovorax avenae subsp. cattleyae, and Acidovorax konjaci. Int. J. Syst. Bacteriol. 42:107-119. 